\title{
Treatment of Produced Water with Photocatalysis: Recent Advances, Affecting Factors and Future Research Prospects
}

\author{
Lu Lin $\mathbb{D}^{\mathbb{B}}$, Wenbin Jiang, Lin Chen, Pei Xu ${ }^{\mathbb{D}}$ and Huiyao Wang * \\ Department of Civil Engineering, New Mexico State University, Las Cruces, NM 88003, USA; \\ lulin@nmsu.edu (L.L.); wbjiang@nmsu.edu (W.J.); chenlin@nmsu.edu (L.C.); pxu@nmsu.edu (P.X.) \\ * Correspondence: huiyao@nmsu.edu
}

Received: 12 July 2020; Accepted: 10 August 2020; Published: 12 August 2020

\begin{abstract}
Produced water is the largest byproduct of oil and gas production. Due to the complexity of produced water, especially dissolved petroleum hydrocarbons and high salinity, efficient water treatment technologies are required prior to beneficial use of such waste streams. Photocatalysis has been demonstrated to be effective at degrading recalcitrant organic contaminants, however, there is limited understanding about its application to treating produced water that has a complex and highly variable water composition. Therefore, the determination of the appropriate photocatalysis technique and the operating parameters are critical to achieve the maximum removal of recalcitrant compounds at the lowest cost. The objective of this review is to examine the feasibility of photocatalysis-involved treatment for the removal of contaminants in produced water. Recent studies revealed that photocatalysis was effective at decomposing recalcitrant organic compounds but not for mineralization. The factors affecting decontamination and strategies to improve photocatalysis efficiency are discussed. Further, recent developments and future research prospects on photocatalysis-derived systems for produced water treatment are addressed. Photocatalysis is proposed to be combined with other treatment processes, such as biological treatments, to partially reduce total organic carbon, break down macromolecular organic compounds, increase biodegradability, and reduce the toxicity of produced water.
\end{abstract}

Keywords: photocatalysis; produced water; water reuse; water treatment; affecting factors; future prospects

\section{Introduction}

Produced water, a byproduct of oil and gas production, is water in underground formations that is brought to the surface during oil and gas production. The methods used for produced water treatment include basic separation technologies designed for the removal of total suspended solids, oil and grease, and advanced treatment technologies designed for the removal of dissolved organic compounds, inorganic ions, and radioactive materials [1-10]. Phase separation underlies basic separation technologies, such as flotation, media filtration, coagulation/flocculation, centrifugation, and hydrocyclone. These basic separation technologies are in most cases incapable of producing an effluent compatible with higher standards for beneficial water reuse [11,12].

The commonly used advanced technologies for produced water treatment consist of membrane filtration, thermal distillation, adsorption, ion exchange, and advanced oxidation processes (AOPs). Nanofiltration and reverse osmosis (RO) are employed for the removal of the majority of organic and inorganic constituents from produced water with total dissolved solids (TDS) concentrations typically below $40 \mathrm{~g} / \mathrm{L}[13,14]$. Other technologies such as thermal distillation are required for produced water 
with higher TDS, such as up to $200 \mathrm{~g} / \mathrm{L}$ [3]. Sorption to activated carbon, biological treatments and AOPs are used for the removal of dissolved organic carbon (DOC) and are often combined with desalination processes to reduce fouling and polish water quality [15].

The removal of dissolved organic compounds in produced water using different treatment technologies was recently reviewed and identified as a bottle-neck for produced water reuse because the organic compounds were not eliminated efficiently $[1,16,17]$. For example, the biological treatment is used to remove organic constituents, especially in the downstream oil and gas industry [18], yet the efficiency of the bioprocess could be severely impeded with the presence of highly toxic recalcitrant compounds, such as benzene, toluene, ethylbenzene, and xylene [19]. The complexity of produced water and the diverse requirements for fit-for-purpose applications (e.g., for generation of high-quality water for steam production, irrigation or aquifer recharge) mandate the development of a multi-step, integrated treatment train, i.e., the combination of different processes, to remove a broad range of constituents. These technologies include pretreatment involving basic separation technologies, treatment using desalination processes, and post-treatment to further polish water quality with AOP, sorption, or re-mineralization. The detailed description of treatment technologies, their advantages and drawbacks, energy consumption and cost efficiency can be found in a number of reviews on produced water treatment [1-3,20-23].

Reactive oxygen or free radical species represent strong oxidants that can initiate AOPs in order to degrade pollutants to simple and nontoxic molecules. Free radical species are atoms or molecules containing at least one unpaired electron, such as hydroxyl radical (HO•), and the superoxide anion radical $\left(\mathrm{O}_{2}-\bullet\right)$, with the $\mathrm{HO} \bullet$ radical having attracted the most attention in this area [24]. AOPs are used in oil- and gas-produced water treatment for the removal of organic and some inorganic compounds, disinfection and the removal of odor and color [3]. Commonly used oxidants include ozone, hydrogen peroxide, chlorine, and Fenton's reagent (combination of hydrogen peroxide with ferrous iron). Produced water treatment technologies based on the combination of hydrodynamic cavitation, ozonation, acoustic cavitation and electrochemical oxidation have been studied for the removal of organic matter, bacteria and scalants, either for flowback reuse or as a pretreatment for $\mathrm{RO}$ [25]. The choice of AOPs mainly depends on the characteristics of the hydroxyl radicals $(\bullet \mathrm{OH})$ generated, as they are highly reactive and have high oxidation potential. This fact enables these species to completely degrade DOCs into $\mathrm{CO}_{2}$ and water, or at least partially into less toxic compounds [26]. The destruction of organic contaminants is the main advantage of AOPs in contrast to other processes such as active carbon, thermal and membrane technologies, which transfer the contaminants from one phase to another [19].

Photocatalytic water treatment is a promising AOP for environmental remediation [27]. Compared to traditional oxidation processes, photocatalytic oxidation operates at ambient conditions without a high temperature or high pressure, and many recalcitrant organic contaminants can be degraded without the addition of chemical oxidants [28]. Moreover, photocatalysis has been proven to be effective at transforming metallic ions and metalloids to less toxic species or species easier to be separated from the system in a subsequent treatment step [29,30]. Since chemical consumption and waste sludge production are one of the major concerns inhibiting produced water treatment, photocatalysis is an attractive technology in comparison with other technologies. However, studies on photocatalytic oxidation of produced water are quite limited, and there is lack of a comprehensive critical review on this field.

For produced water treatment, the efficiency of photocatalysis can be impacted by the different constituents present in a complex matrix composed by a high and heterogeneous concentration of salts [16]. A comprehensive review is needed for further development of AOPs in produced water treatment application. Therefore, this review focuses on evaluating the feasibility of photocatalysis on produced water treatment and the impact of water chemistry. The objective of this work is to examine the suitability of photocatalysis integrated in a multi-stage treatment train based on recent research since 2010. 


\section{Produced Water Characteristics, Treatment and Reuse}

The United States produces an estimate of 890 billion gallons $\left(3.37\right.$ billion $\left.\mathrm{m}^{3}\right)$ of produced water annually, making it the largest waste stream associated with oil and gas activities [31]. The amount of produced water generated every year keeps increasing with the expansion of unconventional oil and gas development, which produced more than $50 \%$ of crude oil and natural gas in 2019 [32]. The oil and gas production in the United States is mainly from seven key oil and gas basins: Appalachia including Marcellus and Utica (Pennsylvania, Ohio, and West Virginia), Bakken (North Dakota and Montana), Eagle Ford (South Texas), Haynesville (Louisiana and East Texas), Niobrara (Colorado and Wyoming), and the Permian basin (West Texas and southeast New Mexico) [33]. Produced water flow rate varies throughout the lifetime of an oil or gas well. Conventional oil and gas wells display little or no produced water at the beginning, with the flow rate increasing over time. Most unconventional hydraulically fractured wells display a high produced water flow rate initially due to the flowback of fracturing fluids, followed by a decay in flow rate until it levels off at a relatively steady lower level [34].

The physical and chemical properties of produced water vary considerably based on the geographic location of the field, the type of hydrocarbon product being extracted, the extraction method employed, and the minerals present in the bearing geologic formation. Since the water has been in contact with hydrocarbon-bearing formations for millennia, it generally contains some of the chemical characteristics of the formations and the hydrocarbons in those formations [35]. Produced water is typically saline with high TDS, including calcium, chloride, magnesium, sodium, and sulfate. Organic compounds are some of the main contaminants in produced water, including oil and grease (free, dispersed or emulsified); volatile and semi-volatile organics, such as benzene, toluene, ethylbenzene, and xylenes (BTEX); polycyclic aromatic hydrocarbons (PAHs); organic acids; and waxes. Contaminants in smaller amounts include dissolved gases (e.g., ammonia and hydrogen sulfide), chemical additives used to improve drilling and production operations, and naturally occurring radioactive materials leached from some formations or precipitated due to water mixing. Additionally, heavy metals and transformational byproducts that can form from the interaction between added chemicals and formation water have also been found in produced water $[9,34,36]$. When collecting data for its 2016 hydraulic fracturing study, the U.S. Environmental Protection Agency found literature reports of about 600 different chemicals in some produced water samples [37]. The concentrations of some select constituents in produced water are summarized in Table 1.

Table 1. Concentrations of select constituents in produced water [35].

\begin{tabular}{cccc}
\hline Parameters & Range & Parameters & Range \\
\hline $\mathrm{pH}$ & $4.3-8.9$ & $\mathrm{Ca}(\mathrm{mg} / \mathrm{L})$ & $18-132,687$ \\
$\mathrm{TDS}(\mathrm{g} / \mathrm{L})$ & $1.0-470.3$ & $\mathrm{Mg}(\mathrm{mg} / \mathrm{L})$ & $4-18,145$ \\
$\mathrm{TSS}(\mathrm{mg} / \mathrm{L})$ & $2-21,820$ & $\mathrm{Na}(\mathrm{mg} / \mathrm{L})$ & $316-134,652$ \\
$\mathrm{DOC}(\mathrm{mg} / \mathrm{L})$ & $3.4-5960$ & $\mathrm{~K}(\mathrm{mg} / \mathrm{L})$ & $8.6-14,649$ \\
Alkalinity $(\mathrm{CaCO}, \mathrm{mg} / \mathrm{L})$ & $6.1-2000$ & $\mathrm{SO}_{4}(\mathrm{mg} / \mathrm{L})$ & $0.5-7851$ \\
Total $\mathrm{Ra}(\mathrm{pCi} / \mathrm{L})$ & $0.2-18,045$ & $\mathrm{Cl}(\mathrm{mg} / \mathrm{L})$ & $1405-310,561$ \\
HEM $(\mathrm{mg} / \mathrm{L})$ & $0.6-2000$ & $\mathrm{HCO}_{3}(\mathrm{mg} / \mathrm{L})$ & $1.9-7355$ \\
MBAS $(\mathrm{mg} / \mathrm{L})$ & $0.01-54$ & $\mathrm{Ba}(\mathrm{mg} / \mathrm{L})$ & $0-22,400$ \\
\hline
\end{tabular}

HEM: Hexane extractable material; MBAS: methylene blue active substances (anionic surfactants); TOC: total organic carbon; TDS: total dissolved solids.

Currently, approximately $45 \%$ of produced water generated from onshore activities in the United States is reused within conventional oil and gas operations for enhanced recovery in conventional oil and gas operations, and well drilling and hydraulic fracturing operations in unconventional oil and gas production [34]. Enhanced recovery techniques include injecting water or steam into the formation to maintain pressure and help sweep more oil to the production wells. Another approach for produced water management is to reuse it outside of the energy sector, such as in irrigation, 
municipal, and industrial sectors, or to discharge treated produced water to surface water or to recharge groundwater. Discharges for agriculture and wildlife propagation are taking place mainly in Wyoming with limited treatment such as settling and/or skimming. In Pennsylvania, produced water usually receives limited or no treatment prior to transfer to the publicly owned treatment works, while in the Marcellus and Utica shale areas of Pennsylvania, Ohio and West Virginia, produced water is disposed via centralized waste treatment facilities by receiving various levels of treatment, from simple physical/chemical treatments to advanced treatment utilizing membranes or distillation [37].

Beneficial uses of produced water outside the energy sector will require much more intensive water treatment than that required to support hydraulic fracturing where minimal treatment (clean brine for hydraulic fracturing) is sufficient [35]. The selection of appropriate technologies should consider the produced water quality, water quality requirements for reuse options, treatment economics, and minimize impacts to environment, local water resources, and public health [10,38]. To optimize produced water reuse, fit-for-purpose treatment will be essential to minimize costs.

\section{Photocatalytic Treatment of Produced Water}

Photocatalysis is a recognized AOP for a variety of pollution remediations. With the irradiation of $\mathrm{UV}$ or visible light, a semiconductor (e.g., $\mathrm{TiO}_{2}$ ) can generate hydroxyl and superoxide anion radicals; then, these radicals can mineralize a wide range of organic compounds [39-42]. Equation (1) displays the general process for organic pollutant degradation by photocatalysis. It is generally accepted that electron-hole pairs are generated on the catalyst $\left(\mathrm{TiO}_{2}\right)$ upon light absorption with light energy higher than its bandgap (Equation (2)). An electron $\left(\mathrm{e}^{-}\right)$in a conductive band and a positive hole $\left(\mathrm{h}^{+}\right)$in the valence band are generated as described by Equation (3). After the dissociation of the exciton, the photogenerated electron and hole migrate to energetically favorable positions. The equilibrium of charge separation depends on diffusion and drift currents, and depends strongly on the rates of charge carrier generation and recombination. Surface water molecules can catch the hole and produce a reactive hydroxyl radical $(\mathrm{OH} \cdot)$ and $\mathrm{H}^{+}$that delocalizes on the nearby water molecules (Equation (4)). Further reaction can lead to the creation of hydrogen peroxide (Equations (5) and (6)), which also promotes the formation of hydroxyl radicals $[43,44]$. The hydroxyl radical and superoxide radical anions (HOO.) are the primary oxidizing species that can lead to oxidation of the organic compounds [45]. Moreover, the volatile constituents in produced water such as methane can be oxidized by the generated hydroxide radicals, and the main product of the photo-induced methane transformation is hydrogen [46]. Recent studies on photocatalysis treatment of produced water are summarized in Table 2.

$$
\begin{aligned}
& \text { Organic pollutant }+\mathrm{O}_{2} \stackrel{\text { semiconductor, hv }}{\rightarrow} \mathrm{CO}_{2}+\mathrm{H}_{2} \mathrm{O}+\text { inorganic ions/acids } \\
& \qquad \begin{array}{c}
\mathrm{TiO}_{2} \stackrel{\text { hv }}{\rightarrow} \mathrm{TiO}_{2}\left(\mathrm{e}^{-}, \mathrm{h}^{+}\right) \\
\mathrm{TiO}_{2}\left(\mathrm{e}^{-}, \mathrm{h}^{+}\right) \leftrightarrow \mathrm{TiO}_{2}\left(\mathrm{e}^{-}\right)+\mathrm{TiO}_{2}\left(\mathrm{~h}^{+}\right) \\
\mathrm{h}^{+}+\mathrm{H}_{2} \mathrm{O} \rightarrow \mathrm{OH} \cdot+\mathrm{H}^{+} \\
\mathrm{e}^{-}+\mathrm{O}_{2}+\mathrm{H}^{+} \rightarrow \mathrm{HOO} \cdot \\
\mathrm{HOO}+\mathrm{HOO} \rightarrow \mathrm{H}_{2} \mathrm{O}_{2}+\mathrm{O}_{2}
\end{array}
\end{aligned}
$$


Table 2. Summary of recent studies on photocatalysis treatment of produced water.

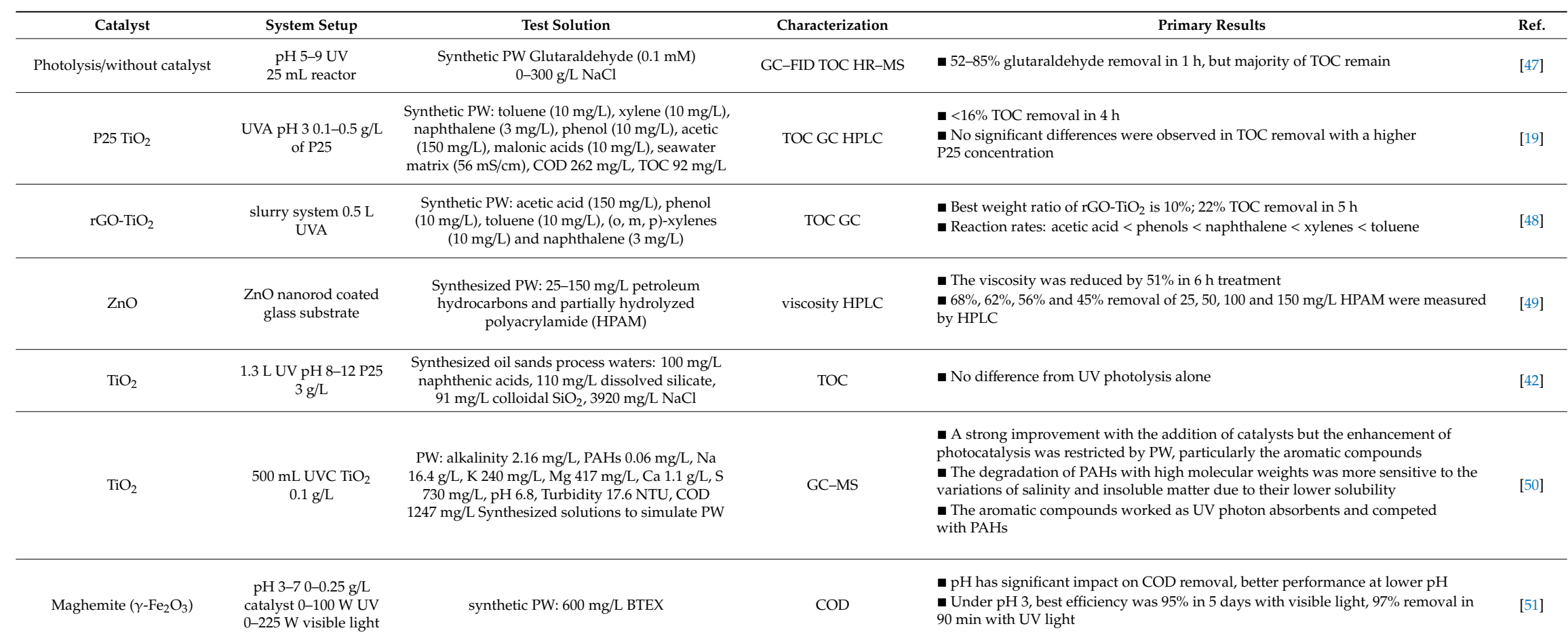

PW: produced water, COD: chemical oxygen demand, TOC: total organic carbon, GC-FID: gas chromatograph-flame ionization detector, HR-MS: high-resolution mass spectrometric, PAHs: polycyclic aromatic hydrocarbons, BTEX: benzene, toluene, ethyl benzene, xylene. 


\subsection{Decomposition and Mineralization}

In the last decade, the study on photocatalytic treatment of produced water was quite limited, and most of the studies used synthetic produced water [19,42,47-50]. The target contaminants were focused on the main groups of contaminants usually present in produced water, including glutaraldehyde, toluene, xylene, naphthalene, phenol, acetic, etc. Some of them could be decomposed quickly, but the mineralization rates of all constituents remained slow. Jimenez et al. [19] investigated different AOPs (photocatalysis, Fenton, and ozonation) on synthetic produced water treatment. Among these techniques, photocatalysis was found to be the less effective for the treatment of produced water, as total organic carbon (TOC) removal was lower than $20 \%$ for the best scenario after $4 \mathrm{~h}$ treatment. No significant differences were observed in TOC removal at a higher $\mathrm{P} 25 \mathrm{TiO}_{2}$ concentration. However, analysis using gas chromatograph-mass spectroscopy (GC-MS) confirmed the total abatement of smaller, volatile organic contaminants (i.e., toluene, xylene and naphthalene) and the decrease in phenol content (up to 99\%). Similar comparison was conducted by Liang et al., they observed no significant reduction in TOC (for large molecular organic constituents such as oil and grease, and natural organic matter) for both $\mathrm{TiO}_{2}$ photocatalysis and $\mathrm{UV}$ photolysis [42]. Graphene-like $\mathrm{TiO}_{2}$ nanocomposites $\left(\mathrm{rGO}-\mathrm{TiO}_{2}\right)$ exhibit higher photocatalytic activity than bare $\mathrm{TiO}_{2}$ in the treatment of synthetic produced water containing high salinity levels and different compositions of recalcitrant dissolved organic matter. The photocatalytic reaction rates increased in the order of acetic acid $<$ phenols $<$ naphthalene $<$ xylenes $<$ toluene, but only 22\% TOC removal in $5 \mathrm{~h} \mathrm{[48].} \mathrm{Partially} \mathrm{hydrolyzed}$ polyacrylamide (HPAM) is a commonly used polymer for enhanced oil recovery. Al-Sabahi et al. reported a new approach to use vertically aligned zinc oxide nanorods supported on substrates engineered for improving their visible light harvesting capacity for effective solar photocatalytic degradation of HPAM. After a $6 \mathrm{~h}$ treatment, 68\%, 62\%, 56\%, and 45\% removal of 25, 50, 100 and $150 \mathrm{mg} / \mathrm{L}$ HPAM, respectively, was reported. Mineralization was observed as 20\% and $37 \%$ TOC reduction after $7 \mathrm{~h}$ and $14 \mathrm{~h}$ reaction times, respectively.

In summary, photocatalysis is demonstrated to be effective at decomposing recalcitrant organic compounds but not to achieve mineralization, which is consistent with other photocatalysis studies on water and wastewater [44,52]. For produced water treatment, it is recommended that multiple technologies be used in series operation to further reduce organic contaminants and intermediate products of photocatalysis. More attention should be paid for toxicity and biodegradability because these parameters significantly influence the design of subsequent treatment processes and overall product water quality.

\subsection{Toxicity}

Different approaches for acute and chronic toxicity evaluation have been applied for photocatalytically treated wastewater effluents such as bioassays with bacteria [53], seawater invertebrates [54], freshwater invertebrates [55], microalgae [53], plants (phytotoxicity) [56], and mammalian cells (genotoxicity) [57]. As reported in the majority of the studies, photocatalytic treatment is effective at decreasing toxicity of wastewater [44].

Even though the number of toxicity studies of photocatalysis increases, limited studies have mentioned toxicity evaluation for produced water treatment. The toxicity test is usually measured on the basis of the median effective concentration $\left(\mathrm{EC}_{50}\right)$, which is the concentration of a substance in an environmental medium expected to produce a certain effect in $50 \%$ of test organisms in a given population under a defined set of conditions. Jimenez et al. used Vibrio fischeri as test organisms to evaluate acute aquatic toxicity according to the basic test methodology. The results can be categorized into four classes depending on their toxicity using $\mathrm{EC}_{50}$ values established by Calleja et al. [58]: class I (very toxic), $\mathrm{EC}_{50} \leq 25 \%$; class II (toxic), when 25\% $<\mathrm{EC}_{50}<75 \%$; class III (slightly toxic), $\mathrm{EC}_{50}=75 \%$; and class IV (non-toxic), $\mathrm{EC}_{50}>75 \%$. The samples treated by photocatalysis ranged between 13 and $16 \%$, which indicates that the effluent resulted somewhat less toxic than the initial produced water $\left(\mathrm{EC}_{50}=10 \%\right)$, in comparison with $40 \%$ for ozone and $57 \%$ for $\mathrm{H}_{2} \mathrm{O}_{2}$ [19]. 
Batch ozone-photocatalytic oxidation using $\mathrm{O}_{3} / \mathrm{UV} / \mathrm{TiO}_{2}$ was performed in a laboratory-scale reactor to evaluate the efficiency of these processes in the degradation of contaminants and/or decrease in the ecotoxicity of produced waters of petroleum refineries [59]. The bacterial luminescence inhibition test using Vibrio fischeri and the fish toxicity test using juvenile guppies (Poecilia vivipara) were conducted in the testing laboratory. Acute toxicity tests showed a high toxicity of the raw effluents $\mathrm{EC}_{50}<1.55 \%$, lower toxicity toward bacteria $\left(\mathrm{EC}_{50}=30.9 \%\right)$ after $60 \mathrm{~min}$ treatment but remained high in fish $\left(\mathrm{EC}_{50}=1.9 \%\right)$. This is because some toxics such as metals and ammonia compounds cannot be eliminated by the photocatalytic treatment, and the treated wastewater samples have significant toxicity toward the fish species, while the bacterial species was more tolerant to the photocatalytic-treated wastewater samples. Post-treatment, such as the biological treatment or the sorption process, is required for further removal of metals and ammonia compounds. Unfortunately, the study did not provide toxicity tests with single photocatalysis, as it is hard to distinguish the effect of photocatalysis from ozone, but it did demonstrate an efficient combination of photocatalysis with ozone to decrease produced water toxicity. More research on toxicity of produced water and photoinduced toxicity is needed to support the application of photocatalytic treatment technologies.

\section{Factors Affecting Photocatalytic Performance}

General factors affecting the photocatalytic activity, including $\mathrm{pH}$, light wavelength and intensity, catalyst dosage, temperature, and concentration of salts and target contaminants, have been fully discussed in other photocatalysis reviews focusing on conventional water and wastewater treatment $[43,52,60,61]$. These factors either depend on the target contaminants or rely on the catalyst properties. Catalyst properties play a critical role for photocatalytic performance and, on account of limited data, they will be discussed in future research prospects (Section 5.5). Factors such as solution $\mathrm{pH}$, catalyst dosage, temperature, and contaminant concentrations cannot be defined given the complexity of produced water and limited removal efficiency (as discussed in Section 2). Moreover, light wavelength and intensity are associated with the catalyst light absorption range and, in addition to high UV absorption of the aromatic compounds in the produced water (as discussed in Section 4.2), they further lower the impact of the light source on photocatalysis. Because the scope of the present work is focused on the factors affecting photocatalytic performance on treating produced water, we primarily discuss the factors that are associated with produced water chemistry.

\subsection{Ionic Species in Produced Water}

The presence of ionic species in produced water can affect the photocatalytic degradation [39,41]. Ionic substances such as chloride, carbonate, bicarbonate, nitrate, nitrite, and phosphate ions can affect photoelectrons generation, electron-hole recombination, and hydroxyl radical scavenging. The reaction of hydroxyl radical with chloride, carbonate and bicarbonate ions can be described in the following equations [43]:

$$
\begin{aligned}
& \mathrm{Cl}^{-}+\mathrm{HO} \cdot \rightarrow \mathrm{Cl} \cdot+\mathrm{OH}^{-} \\
& \mathrm{CO}_{3}^{2-}+\mathrm{HO} \cdot \rightarrow \mathrm{CO}_{3}^{-} \cdot+\mathrm{OH}^{-} \\
& \mathrm{HCO}_{3}^{-}+\mathrm{HO} \cdot \rightarrow \mathrm{CO}_{3}^{-} \cdot+\mathrm{H}_{2} \mathrm{O}
\end{aligned}
$$

Among these inorganic anions, chloride ions can play a detrimental effect on photocatalytic treatment by scavenging holes and hydroxyl radicals, given rise to the generation of less reactive chloride radical (Cl-) and dichloride radicals $\left(\mathrm{Cl}_{2}^{-}\right)$(Equations (10)-(12)) [62].

$$
\begin{gathered}
\mathrm{Cl}^{-}+\mathrm{h}_{\mathrm{vb}}^{+} \leftrightarrow \mathrm{Cl} \\
\mathrm{Cl}^{-}+\mathrm{HO} \cdot \leftrightarrow \mathrm{ClOH}^{-} \\
\mathrm{Cl}^{-}+\mathrm{Cl} \cdot \rightarrow \mathrm{Cl}_{2}^{-}
\end{gathered}
$$




\subsection{Organics in Produced Water}

Organics are one of the prominent inhibitors for produced water treatment. Because photocatalysis is a combined process of adsorption and degradation, the existence of organics in produced water can affect removal efficacy of these two processes. The organic matter can prevent the breakdown of contaminants through site blockage, hydroxyl scavenging, and light absorption [63]. Recalcitrant compounds present in produced water, such as acetic acid and toluene, have a low reaction rate with radicals, which makes them refractory and hard to decompose [19]. Studies treating recalcitrant-to-OH-radicals components, such as acetic acid, phenol, and naphthalene, in produced water, are scarce and the removal efficiencies were reported to be low [48]. Catechol, dihydroxy benzenes, hydroquinone, and resorcinol were found to hinder severely photocatalytic reactions [64]. It was reported that some wastewater-derived organic matter could scavenge up to $95 \%$ of hydroxyl radicals [65]. The effects of insoluble particulate matter and organic composition of produced water on photocatalytic performance were evaluated by Liu et al. [50]. The organic composition was found the more likely factor retarding the breakdown of PAHs. In addition, the aromatic compounds played a key role in absorbing UV photons owing to their abundance and UV sensitivity. Moreover, the aromatic species can compete with PAHs for adsorption sites and activated species during the photocatalytic process. Hence, aromatic substances of high concentrations could significantly reduce the overall photocatalytic activity.

\section{Future Research Perspectives}

As shown in Figure 1, interests in photocatalytic treatment of produced water are growing remarkably, but only a few studies are employing photocatalysis into produced water treatment, as summarized in Table 2. Hence, more research is required to evaluate photocatalytic performance in produced water treatment. Future research directions are suggested in this section.

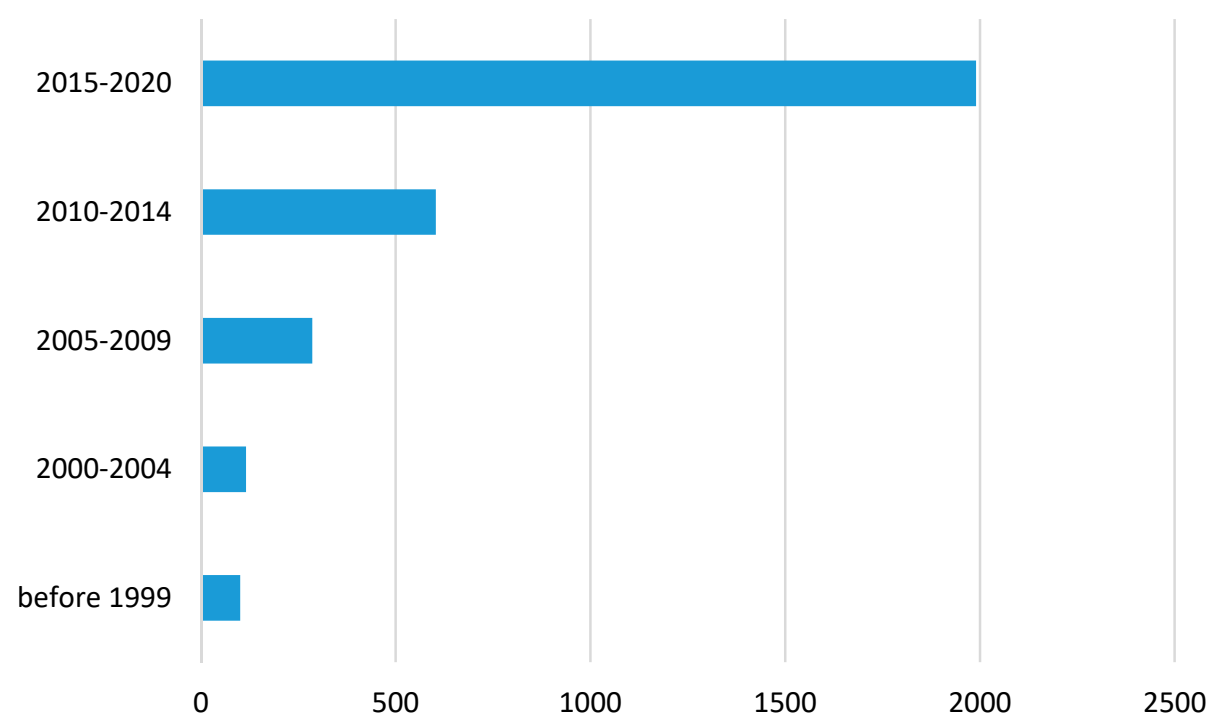

Figure 1. Number of publications mentioning photocatalysis and produced water. Data collected from Google Scholar.

\subsection{Biodegradability Improved with Photocatalysis}

As discussed in Section 3.1, photocatalysis could not achieve complete removal of TOC from produced water as a stand-alone treatment process. Photocatalysis can be coupled with other treatment processes such as the biological treatment to increase the treatment efficiency of both processes $[60,66]$. The nonselective reactivity of radicals on the non-biodegradable water-soluble pollutants determines that the photocatalytic process can be used effectively as a pre-treatment step to enhance biodegradation 
of recalcitrant organic pollutants prior to biological water treatment. Hence, future work should focus more on demonstrating its efficiency in degrading a wide range of ambiguous refractory organics into readily biodegradable compounds, instead of achieving mineralization to innocuous carbon dioxide and water.

The biodegradability can be measured by the ratio of biochemical oxygen demand (BOD) and chemical oxygen demand (COD), where a low ratio represents low biodegradability of the organic compounds present in the solution. The BOD/COD ratio of produced water can be less than 0.1 [67], indicating the non-degradability proprieties of the produced water and the requirement of advanced treatment. The increase in biodegradability, i.e., a higher BOD/COD ratio, suggests macromolecular and bio-refractory organic matter could have been degraded to smaller molecules and become more biodegradable. The BOD/COD ratio can be used as a simple, straightforward indicator for photocatalysis to exhibit a great contribution to the biodegradability improvement of produced water, making the produced water more suitable for microbial growth.

\subsection{Toxicity of Catalysts}

The concerns regarding catalyst toxicity as engineered nanomaterials have risen in recent years towards the potential risks and toxicology to human health and the environment. This is associated with the fact that photocatalytic nanoparticles (e.g., $\mathrm{TiO}_{2}$ nanoparticles) have been widely used in personal care products, such as sunscreens and chewing gums. There are increasing concerns regarding the potential risks of the nanoparticles to human health due to the direct and repeated exposure [68]. Debates are further powered by complaints and warnings from toxicologist and researchers all over the world that arise from the challenges related to the toxicity assessment of nanomaterials [68]. In addition, not all the synthesized materials have been considered in toxicity studies and the juvenility of nanotechnology impedes realistic exposure scenarios.

In the last decade, the number of publications studying toxicity of nanomaterials has increased continuously. $\mathrm{TiO}_{2}$ nanoparticles have shown a toxic effect on numerous organisms and cell lines, including algae [69,70], bacteria [71-73], fungi [74], human keratinocytes [75,76], and water organisms like Daphnia magna $[77,78]$ and fish $[79,80]$. In most of the studies, toxicity relied on nanoparticle concentration as well as irradiation intensity and duration. Phototoxicity was also reported on $\mathrm{CuO}$ [81], $\mathrm{ZnO}$ [69], and CdSe/ZnSe quantum dots [82] when they were irradiated with UV-containing light.

Friehs et al. reviewed photocatalytically active nanoparticles extensively for numerous environmental and energy related applications [68]. They summarized two main mechanisms of phototoxic effect on living organism: the production of reactive oxygen species and the dissolution of metal ions [83]. However, most phototoxicity studies are focused on $\mathrm{TiO}_{2}$, mainly $\mathrm{P} 25$, and there was also a limited species diversity in nanotoxicity studies [84]. Only a small amount of the materials and the respective doping, coatings or other modifications that alter their physicochemical properties have been studied. Moreover, the high number of parameters that can influence the outcome of experiments may lead to inconsistent and conflicting data [85], thereby not allowing meaningful extrapolation of the conclusions to other nanomaterials. Therefore, toxicity of catalysts should be carefully investigated to ensure safe application of photocatalysis and other AOPs to produced water treatment.

\subsection{Photoinduced Intermediates}

To evaluate the suitability and niche of photocatalysis in produced water treatment trains, there is a great need to understand the toxicity of the intermediates generated during photocatalysis. Meanwhile, the identification of key photoinduced intermediates can help fully elucidate the reaction mechanism. The detection of intermediates can be achieved by conducting high-performance liquid chromatography with tandem mass spectrometry (LC-MS/MS) analysis, which can qualitatively and quantitatively determine the organic intermediates even at trace concentrations. Several research groups have studied the photochemical and photocatalytic degradation of various organic contaminants, including pharmaceuticals (e.g., ibuprofen, metoprolol) [40,86], insecticide (e.g., thiacloprid) [87], phenol [88], 
4-chlorophenol [89], etc. To the best of our knowledge, to date, there is no study on the detection of intermediate products for produced water treatment.

Intensive attention has been devoted to the characterization of organic compounds in produced water in recent years. There are several advanced analytical techniques for characterizing and quantifying dissolved organic matter, including gas chromatography coupled with flame ionization detector (GC-FID), thermal conductivity detector (GC-TCD) or mass spectrometry (GC-MS) and liquid chromatography (LC) coupled with UV diode array detector (LC-UV), organic carbon detection (LC-OCD) or mass spectrometry (LC-MS). GC-based methods are extensively used for analysis of volatile and semivolatile compounds, including natural gas constituents (methane and ethane), BTEX (benzene, toluene, ethyl benzene, xylene), and diesel-range semivolatile organics. LC-based techniques are more suitable for non-volatile organic compounds, such as surfactants, fatty amines, and high molecular weight ionic polyacrylamide friction reducers [90]. Mass spectrometry (MS) is the most powerful detector to characterize complex fluids and has been extensively used for PW analysis. It can provide qualitative and quantitative information about the analytes with the help of standards or mass spectral libraries. Tandem high-resolution mass spectrometry (HRMS/MS) can provide crucial information to elucidate the elemental composition and structure of the compounds in the sample. The mostly widely used HRMS/MS includes quadrupole-time of flight mass analyzer (Q-ToF), orbitrap mass analyzer, and Fourier transform ion cyclotron resonance mass spectrometry (FT-ICR-MS).

Nontarget analysis is a critical tool to identify the intermediates due to their "unknown" property. Nontarget analysis heavily relies on HSMS/MS, such as Q-ToF, Orbitrap mass analyzer, and FT-ICR-MS. This approach requires no prior information about the unknown chemicals in the sample. The basic procedure for nontarget analysis is first to collect the mass spectra of unknown chemicals, and data processing techniques are used to assign potential molecular formula [91,92]. Chemical structure identification is achieved by database spectra-searching or matching the MS/MS spectra and retention time with reference standards. HSMS/MS has been used to identify the degraded products of organic compounds in produced water during hydraulic fracturing and biological treatments $[93,94]$.

\subsection{Photo-Detoxication of Heavy Metals}

Photocatalysis has been demonstrated to convert the ionic species into their metallic solid form and deposit them over the semiconductor surface or transform them into less toxic soluble species. When a transformation to the zero-valent state is possible, this allows the recovery of the metal from the water, with an economic return [29,30]. Produced water contains heavy metals such as mercury and lead, as well as metalloids such as arsenic, in varied concentrations depending on formation geology and age of the well $[1,95]$. Concentrations of heavy metals in produced water are usually higher than those found in sea water; commonly studied metals include $\mathrm{Ba}, \mathrm{Cd}, \mathrm{Cr}, \mathrm{Cu}, \mathrm{Pb}, \mathrm{Hg}, \mathrm{Ni}, \mathrm{Ag}$, and $\mathrm{Zn}[3,95,96]$. Produced water contains other trace metals, including Al, B, Fe, Li, Mn, Se, and Sr. Certain metals are of particular environmental concern as they may bioaccumulate and/or be toxic [96]. Although heavy metals are not primary contaminants of produced water, photo-detoxication of heavy metals can reduce the toxicity of produced water and facilitate reuse applications.

Heavy metals such as hexavalent chromium $(\mathrm{Cr}(\mathrm{VI}))$ present the highest environmental threat due to their toxicity for biological organisms together with their high solubility and mobility, while $\mathrm{Cr}(\mathrm{III})$ is considered non-toxic or of very low toxicity, and their mobility is lower than those of $\mathrm{Cr}(\mathrm{VI})$ [97]. The removal of $\mathrm{Cr}(\mathrm{VI})$ by photocatalytic-induced reduction reaction is highly efficient and environmentally friendly. A number of studies have been published on the photocatalytic reduction in $\mathrm{Cr}(\mathrm{VI})$ employing $\mathrm{TiO}_{2}$, modified $\mathrm{TiO}_{2}$, and other semiconductors, such as $\mathrm{ZnO}, \mathrm{CdS}, \mathrm{ZnS}$, and $\mathrm{WO}_{3}$, which have already been described in other reviews [98-100]. Another example of metalloids is arsenic, which mainly comes from natural sources due to dissolution of minerals in surface or groundwaters or volcanic processes $[101,102]$. Previous studies demonstrated that photocatalytic treatment is an efficient approach to promote oxidation of arsenite(III) to arsenate(V) [103]. Transformation to As(V) makes it easier to use conventional technologies, e.g., ion exchange and adsorption [30]. Nevertheless, 
to date, limited research on heavy metal treatment from produced water has been reported. The toxicity of heavy metals in produced water is another concern for future produced water management.

\subsection{Catalysts}

As shown in Table 2, almost all photocatalytic treatments of produced water have been reported to be low in efficiency and require a longer reaction time (e.g., in hours). Various strategies have been adopted to improve the electron-hole pair recombination and narrow the band gap to widen the absorbance from UV to visible light range. However, the main reasons for low photocatalytic efficiency in produced water could be attributed to low efficiency of illumination and quick poisoning of catalysts. Given the complex composition of produced water, light transfer could be limited by the suspended solids and absorbing and scattering liquid to the catalyst. In addition, a large number of constituents could accumulate on the catalysts surface and further reduce the light reaching the catalysts, resulting in low efficiency and catalyst inactivation. Therefore, photocatalysis is not effective when applied to raw produced water and requires a certain level of pre-treatment.

Another option is to enhance the surface area of catalysts that provides a larger illuminated surface to absorb light. The suspended configuration is related to a high volumetric generation rate of reactive oxygen species in proportion to the active sites of catalysts used in suspension [103]. Still, a supplementary system to separate catalysts from the treated water needs a new process to overcome catalyst loss and its introduction into the environment. Immobilized configuration eliminates the subsequent separation system, but the light reflection by the photocatalyst support and the reduced amount of the active site together with the enlarged mass transfer limitation poses a serious concern that needs to be addressed.

A third option is to eliminate the constraints associated with operating parameters. Since the chemical composition and $\mathrm{pH}$ of produced water varies considerably from formation to formation and well to well, efforts should be made in the area of catalyst modification for a wide range of operating conditions, such as temperature, $\mathrm{pH}$ and contaminant concentrations. The impact of modification methods on catalyst properties cannot be ignored. The hydrothermally prepared catalysts often contain physiosorbed and lattice water, which may contribute to the efficiency of photocatalysts, and lattice water may help the separation of the electron-hole pairs [104,105]. It has also been reported that there are cationic impurities in the lattice on the electronic properties of synthesized catalysts $[106,107]$. Practice reveals the controversial results of metal-doping catalysts, which can be explained by the competing processes of photogeneration and recombination of electron and hole pairs [104,108]. Additionally, research should also be conducted on semiconductor modifications to achieve a self-cleaning capability. Modification of catalysts can optimize interactions of catalyst particles and organic pollutants, thus resisting contaminant accumulation on the catalyst's surface and reducing the risk of catalyst poison.

\section{System Integration}

High concentrations of ionic species and recalcitrant organics in produced water require a holistic treatment solution with the consideration of an integrated multiple processes approach. Light absorption and scattering in produced water can significantly reduce the irradiation reception of a catalyst. In order to enhance the photocatalytic performance in treating produced water, physical separation processes, such as an oil-water separator, a coalescer or hydrocyclones, are required to eliminate suspended solids, oil and grease [109].

After physical separation, biological processes can be employed to further reduce organic constituents in produced water effluent [110]. However, due to the complexity of produced water, some constituents are difficult to be removed biologically and often persist after a conventional secondary biological treatment. Photocatalysis can breakdown residual compounds in many industrial wastewaters that are hardly biodegradable [111]. Therefore, a combination of photocatalysis with 
the biological treatment is suggested to minimize treatment costs and improve the overall treatment efficiency, as shown in Figure 2.

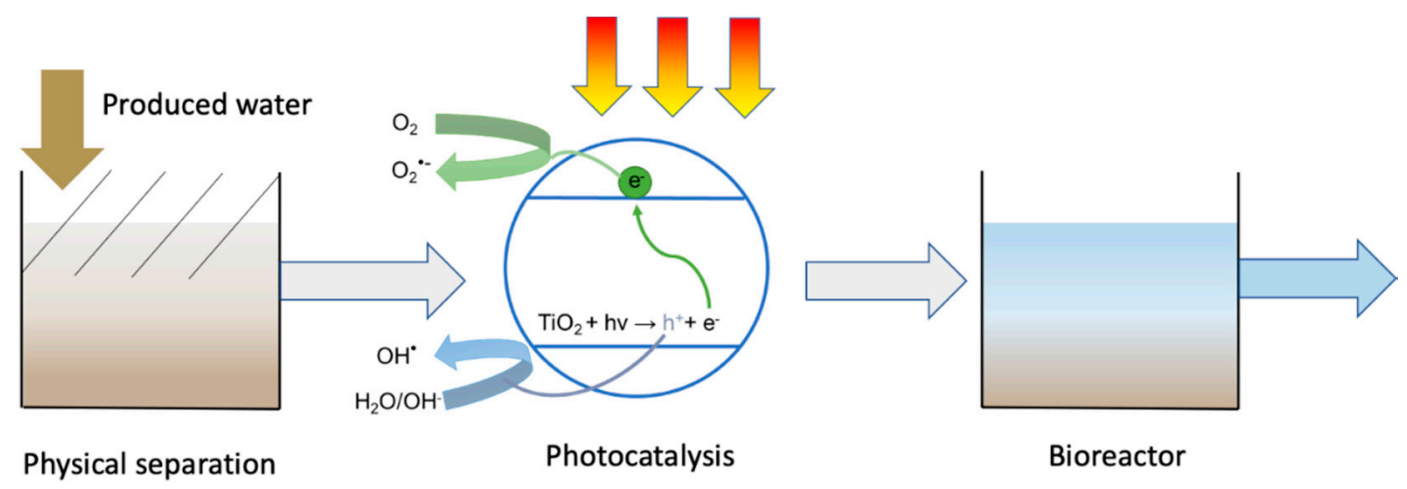

Figure 2. Proposed produced water treatment train.

Although the combination of photocatalysis and biodegradation has been proved to be effective in wastewater treatment [111-114], the application in produced water is still quite limited with only one reported study thus far. Correa et al. investigated the efficiency of an ozone-photocatalyzed $\mathrm{O}_{3} / \mathrm{UV} / \mathrm{TiO}_{2}$ oxidation process followed by biological remediation for produced water treatment. The result was promising-after a $5 \mathrm{~min} \mathrm{O}_{3} / \mathrm{UV} / \mathrm{TiO}_{2}$ oxidation process, phenol concentration decreased by $99.9 \%$, sulfide by $53.0 \%$, COD by $37.7 \%$, oil and grease by $5.2 \%$, and ammonia by $1.9 \%$, while after $60 \mathrm{~min}$ of oxidation treatment, the removal efficiency increased to $99.9 \%$ for phenols, $98.2 \%$ for oil and grease, $97.2 \%$ for sulfide, $89.2 \%$ for COD, and $15 \%$ for ammonia. The acute toxicity tests with the bacterium Vibrio fischeri and the fish Poecilia vivipara revealed that produced water presented a high toxicity ( $\mathrm{EC}_{50}<1.55 \%$ for both species). The combined oxidation and biological process showed a significant toxicity reduction with $\mathrm{EC}_{50}=89.2 \%$ for bacteria and $\mathrm{EC}_{50}=85.7 \%$ for fish [59].

The concept of a physical separation (photocatalysis) biotreatment would not only improve the activity of the biological treatment, but also improve the water quality of product water by toxicity reduction. In addition, photocatalysis can be also used as a post-treatment to polish the product water quality by degrading organic residuals. More research is required to further prove the feasibility of the combined system for produced water treatment.

\section{Conclusions}

In order to meet the needs of environmental regulations as well as reuse and recycling of produced water, extensive efforts have been devoted to investigating produced water treatment technologies. In produced water treatment, no single technology can meet suitable water quality requirements, therefore, multiple technologies have to be used to remove a wide range of contaminants. Choice of the best technology depends on the chemistry of the produced water, cost effectiveness, space availability, reuse and discharge plans, durable operation, and byproducts. Photocatalysis is a promising destructive technology due to low or no chemical consumption and no waste sludge production during the treatment. Studies on photocatalytic oxidation of produced water are quite limited, and there is a lack of a comprehensive understanding of the applicability of photocatalysis and the strategies to improve the treatment efficacy. The objective of the present work is to critically review the feasibility of photocatalysis-involved treatment solutions and factors affecting produced water treatment.

Photocatalytic activity can be significantly impacted by the aqueous chemistry of produced water. Ionic substances, such as chloride, carbonate, bicarbonate, nitrate, nitrite, and phosphate ions, can affect photoelectrons generation, electron-hole recombination and hydroxyl radical scavenging. However, ionic strength caused by chloride, calcium, magnesium, and sulfate can change the type and concentration of adsorption sites and the electrostatic interactions in the interface of a solution 
and catalyst. High organic contents are one of the prominent inhibitors for produced water treatment through site blockage, hydroxyl scavenging, and light adsorption. In order to enhance the photocatalytic performance in treating produced water, conventional physical separation processes are required to eliminate suspended solids, oil and grease.

Research on photocatalytic treatment of produced water is very limited, and most studies used synthetically produced water. The results revealed that photocatalysis was effective at decomposing recalcitrant organic compounds but not for achieving mineralization. Therefore, photocatalysis can be used as a pretreatment with other treatment processes such as biological treatments to partially reduce TOC, break down macromolecular organic compounds, increase biodegradability, and reduce the toxicity of produced water. Photocatalysis can be also used as a post-treatment to polish the product water quality by removing contaminant residuals. In addition, there is a research need for the modification of photocatalysts that are adaptive and flexible for a wide range of operating conditions, with an improved specific surface area and self-cleaning capability.

Author Contributions: L.L., W.J., L.C., P.X. and H.W. wrote the original draft and reviewed and edited the manuscript. H.W. and P.X. acquired research funding. H.W. managed the research project. All authors have read and agreed to the published version of the manuscript.

Funding: The authors thank the United States Bureau of Reclamation Desalination and Water Purification Research and Development Program (Agreement No. R19AC00109) and ExxonMobil Upstream Research Company for financial support of the research.

Conflicts of Interest: The authors declare no conflict of interest. The funders had no responsibility in the design of the study; in the collection, analyses, or interpretation of data; in the writing of the manuscript, or in the decision to publish the results.

\section{References}

1. Fakhru'L-Razi, A.; Pendashteh, A.; Abdullah, L.C.; Biak, D.R.A.; Madaeni, S.S.; Abidin, Z.Z. Review of technologies for oil and gas produced water treatment. J. Hazard. Mater. 2009, 170, 530-551. [CrossRef]

2. Arthur, J.D.; Langhus, B.G.; Patel, C. Technical Summary of Oil \& Gas Produced Water Treatment Technologies; All Consulting, LLC: Tulsa, OK, USA, 2005.

3. Igunnu, E.T.; Chen, G.Z. Produced water treatment technologies. Int. J. Low Carbon Technol. 2012, 9, $157-177$. [CrossRef]

4. Xu, P.; Drewes, J.E. Viability of nanfiltration and ultra-low pressure reverse osmosis membranes for multi-beneficial use of methane produced water. Sep. Purif. Technol. 2006, 52, 67-76. [CrossRef]

5. Xu, P.; Drewes, J.E.; Heil, D. Beneficial use of co-produced water through membrane treatment: Technical-economic assessment. Desalination 2008, 225, 139-155. [CrossRef]

6. Hickenbottom, K.L.; Hancock, N.T.; Hutchings, N.R.; Appleton, E.W.; Beaudry, E.G.; Xu, P.; Cath, T.Y. Forward osmosis treatment of drilling mud and fracturing wastewater from oil and gas operations. Desalination 2013, 312, 60-66. [CrossRef]

7. Stoll, Z.A.; Forrestal, C.; Ren, Z.J.; Xu, P. Shale gas produced water treatment using innovative microbial capacitive desalination cell. J. Hazard. Mater. 2015, 283, 847-855. [CrossRef]

8. Hu, L.; Yu, J.; Luo, H.; Wang, H.; Xu, P.; Zhang, Y. Simultaneous recovery of ammonium, potassium and magnesium from produced water by struvite precipitation. Chem. Eng. J. 2020, 382, 123001. [CrossRef]

9. Rodriguez, A.Z.; Wang, H.; Hu, L.; Zhang, Y.; Xu, P. Treatment of Produced Water in the Permian Basin for Hydraulic Fracturing: Comparison of Different Coagulation Processes and Innovative Filter Media. Water 2020, 12, 770. [CrossRef]

10. Geza, M.; Ma, G.; Kim, H.; Cath, T.Y.; Xu, P. iDST: An integrated decision support tool for treatment and beneficial use of non-traditional water supplies-Part I. Methodology. J. Water Process. Eng. 2018, 25, $236-246$. [CrossRef]

11. Dores, R.; Hussain, A.; Katebah, M.; Adham, S.S. Using Advanced Water Treatment Technologies to Treat Produced Water from the Petroleum Industry. In Proceedings of the SPE International Production and Operations Conference \& Exhibition, Doha, Qatar, 14-16 May 2012. 
12. Hussain, A.; Minier-Matar, J.; Janson, A.; Gharfeh, S.; Adham, S. Advanced technologies for produced water treatment and reuse. In Proceedings of the International Petroleum Technology Conference, European Association of Geoscientists \& Engineers, Doha, Qatar, 19-22 January 2014; No. 1. pp. 1-11.

13. Munirasu, S.; Abu Haija, M.; Banat, F. Use of membrane technology for oil field and refinery produced water treatment-A review. Process. Saf. Environ. Prot. 2016, 100, 183-202. [CrossRef]

14. Alzahrani, S.; Mohammad, A.W. Challenges and trends in membrane technology implementation for produced water treatment: A review. J. Water Process. Eng. 2014, 4, 107-133. [CrossRef]

15. Boschee, P. Handling Produced Water from Hydraulic Fracturing. Oil Gas Facil. 2012, 1, 22-26. [CrossRef]

16. Jiménez, S.; Micó, M.M.; Arnaldos, M.; Medina, F.; Contreras, S. State of the art of produced water treatment. Chemosphere 2018, 192, 186-208. [CrossRef] [PubMed]

17. Butkovskyi, A.; Bruning, H.; Kools, S.A.; Rijnaarts, H.; Van Wezel, A.P. Organic Pollutants in Shale Gas Flowback and Produced Waters: Identification, Potential Ecological Impact, and Implications for Treatment Strategies. Environ. Sci. Technol. 2017, 51, 4740-4754. [CrossRef] [PubMed]

18. Pendashteh, A.; Fakhru'L-Razi, A.; Chuah, T.; Radiah, A.D.; Madaeni, S.; Zurina, Z. Biological treatment of produced water in a sequencing batch reactor by a consortium of isolated halophilic microorganisms. Environ. Technol. 2010, 31, 1229-1239. [CrossRef] [PubMed]

19. Jiménez, S.; Andreozzi, M.; Micó, M.M.; Álvarez, M.G.; Contreras, S. Produced water treatment by advanced oxidation processes. Sci. Total Environ. 2019, 666, 12-21. [CrossRef] [PubMed]

20. Saba, B. Potential Treatment Options for Hydraulic Fracturing Return Fluids: A Review. ChemBioEng Rev. 2014, 1, 273-279. [CrossRef]

21. Abousnina, R.M.; Nghiem, L.D.; Bundschuh, J. Comparison between oily and coal seam gas produced water with respect to quantity, characteristics and treatment technologies: A review. Desalin. Water Treat. 2014, 54, 1793-1808. [CrossRef]

22. Estrada, J.M.; Bhamidimarri, R. A review of the issues and treatment options for wastewater from shale gas extraction by hydraulic fracturing. Fuel 2016, 182, 292-303. [CrossRef]

23. Xu, P.; Stoll, Z.; Ma, G.; Geza, M.; Cath, T.Y.; Drewes, J. Technical Assessment of Produced Water Treatment Technologies. An Integrated Framework for Treatment and Management of Produced Water; Final Report to Department of Energy Project 11122-53; New Mexico State University-Colorado School of Mines: Las Cruces, NM, USA; Golden, CO, USA, 2016.

24. Kanakaraju, D.; Glass, B.D.; Oelgemöller, M. Advanced oxidation process-mediated removal of pharmaceuticals from water: A review. J. Environ. Manag. 2018, 219, 189-207. [CrossRef]

25. Ely, J.W.; Fraim, M.; Horn, A.D.; Jakhete, S.D. Game changing technology for treating and recycling frac water. In Proceedings of the SPE Annual Technical Conference and Exhibition, Denver, CO, USA, 30 October-2 November 2011.

26. Lin, L.; Wang, H.; Xu, P. Immobilized TiO2-reduced graphene oxide nanocomposites on optical fibers as high performance photocatalysts for degradation of pharmaceuticals. Chem. Eng. J. 2017, 310, 389-398. [CrossRef]

27. Lin, L.; Wang, H.; Jiang, W.; Mkaouar, A.R.; Xu, P. Comparison study on photocatalytic oxidation of pharmaceuticals by $\mathrm{TiO} 2-\mathrm{Fe}$ and $\mathrm{TiO} 2$-reduced graphene oxide nanocomposites immobilized on optical fibers. J. Hazard. Mater. 2017, 333, 162-168. [CrossRef] [PubMed]

28. Lin, L.; Wang, H.; Luo, H.; Xu, P. Enhanced photocatalysis using side-glowing optical fibers coated with Fe-doped TiO2 nanocomposite thin films. J. Photochem. Photobiol. A: Chem. 2015, 307, 88-98. [CrossRef]

29. Braslavsky, S.E.; Braun, A.M.; Cassano, A.E.; Emeline, A.V.; Litter, M.I.; Palmisano, L.; Parmon, V.N.; Serpone, N. Glossary of terms used in photocatalysis and radiation catalysis (IUPAC Recommendations 2011). Pure Appl. Chem. 2011, 83, 931-1014. [CrossRef]

30. Litter, M.I. Mechanisms of removal of heavy metals and arsenic from water by TiO2-heterogeneous photocatalysis. Pure Appl. Chem. 2015, 87, 557-567. [CrossRef]

31. Veil, J. U.S. Produced Water Volumes and Management Practices in 2012; Ground Water Protection Council: Oklahoma City, OK, USA, 2015; Available online: http://www.veilenvironmental.com/publications/pw/final_ report_CO_note.pdf (accessed on 1 August 2020).

32. U.S. EIA. Annual Energy Outlook 2019: With Projections to 2050; US Energy Information Administration Office of Energy Analysis, U.S. Department of Energy: Washington, DC, USA, 2019. Available online: https://www.eia.gov/outlooks/aeo/pdf/aeo2019.pdf (accessed on 1 August 2020). 
33. U.S. EIA. Drilling Productivity Report; US Energy Information Administration Independent Statistics \& Analysis: Washington, DC, USA, 2020. Available online: https://www.eia.gov/petroleum/drilling/ (accessed on 1 August 2020).

34. Produced Water Report: Regulations, Current Practices, and Research Needs. 2019. Available online: http://www.gwpc.org/sites/default/files/files/Produced\%20Water\%20Full\%20Report\%20\%20Digital\%20Use.pdf (accessed on 1 August 2020).

35. Scanlon, B.R.; Reedy, R.C.; Xu, P.; Engle, M.A.; Nicot, J.; Yoxtheimer, D.; Yang, Q.; Ikonnikova, S. Can we beneficially reuse produced water from oil and gas extraction in the U.S.? Sci. Total Environ. 2020, 717, 137085. [CrossRef]

36. Chaudhary, B.K.; Sabie, R.; Engle, M.A.; Xu, P.; Willman, S.; Carroll, K.C. Spatial variability of produced-water quality and alternative-source water analysis applied to the Permian Basin, USA. Hydrogeol. J. 2019, 27, 2889-2905. [CrossRef]

37. Study of Oil and Gas Extraction Wastewater Management under the Clean Water Act. 2019. Available online: https://www.epa.gov/sites/production/files/2019-05/documents/oil-and-gas-study_draft_05-2019.pdf (accessed on 1 August 2020).

38. Ma, G.; Geza, M.; Cath, T.Y.; Drewes, J.E.; Xu, P. iDST: An integrated decision support tool for treatment and beneficial use of non-traditional water supplies-Part II. Marcellus and Barnett Shale case studies. J. Water Process. Eng. 2018, 25, 258-268. [CrossRef]

39. Lin, L.; Jiang, W.; Nasr, M.; Bechelany, M.; Miele, P.; Wang, H.; Xu, P.; Lu, L. Enhanced visible light photocatalysis by $\mathrm{TiO} 2-\mathrm{BN}$ enabled electrospinning of nanofibers for pharmaceutical degradation and wastewater treatment. Photochem. Photobiol. Sci. 2019, 18, 2921-2930. [CrossRef]

40. Lin, L.; Jiang, W.; Bechelany, M.; Nasr, M.; Jarvis, J.; Schaub, T.; Sapkota, R.R.; Miele, P.; Wang, H.; Xu, P. Adsorption and photocatalytic oxidation of ibuprofen using nanocomposites of $\mathrm{TiO} 2$ nanofibers combined with BN nanosheets: Degradation products and mechanisms. Chemosphere 2019, 220, 921-929. [CrossRef]

41. Lin, L.; Wang, H.; Luo, H.; Xu, P. Photocatalytic Treatment of Desalination Concentrate Using Optical Fibers Coated With Nanostructured Thin Films: Impact of Water Chemistry and Seasonal Climate Variations. Photochem. Photobiol. 2016, 92, 379-387. [CrossRef] [PubMed]

42. Liang, X.; Zhu, X.; Butler, E.C. Comparison of four advanced oxidation processes for the removal of naphthenic acids from model oil sands process water. J. Hazard. Mater. 2011, 190, 168-176. [CrossRef] [PubMed]

43. Ahmad, R.; Ahmad, Z.; Khan, A.U.; Mastoi, N.R.; Aslam, M.; Kim, J. Photocatalytic systems as an advanced environmental remediation: Recent developments, limitations and new avenues for applications. J. Environ. Chem. Eng. 2016, 4, 4143-4164. [CrossRef]

44. Rueda-Marquez, J.J.; Levchuk, I.; Ibañez, P.F.; Sillanpää, M. A critical review on application of photocatalysis for toxicity reduction of real wastewaters. J. Clean. Prod. 2020, 258, 120694. [CrossRef]

45. Kiss, J.; Kukovecz, Á.; Kónya, Z. Beyond Nanoparticles: The Role of Sub-nanosized Metal Species in Heterogeneous Catalysis. Catal. Lett. 2019, 149, 1441-1454. [CrossRef]

46. László, B.; Baán, K.; Varga, E.; Oszkó, A.; Erdőhelyi, A.; Konya, Z.; Kiss, J. Photo-induced reactions in the CO 2 -methane system on titanate nanotubes modified with Au and Rh nanoparticles. Appl. Catal. B: Environ. 2016, 199, 473-484. [CrossRef]

47. Hong, S.; Ratpukdi, T.; Sivaguru, J.; Khan, E. Photolysis of glutaraldehyde in brine: A showcase study for removal of a common biocide in oil and gas produced water. J. Hazard. Mater. 2018, 353, 254-260. [CrossRef]

48. Andreozzi, M.; Álvarez, M.; Contreras, S.; Medina, F.; Clarizia, L.; Vitiello, G.; Llorca, J.; Marotta, R. Treatment of saline produced water through photocatalysis using rGO-TiO2 nanocomposites. Catal. Today 2018, 315, 194-204. [CrossRef]

49. Al-Sabahi, J.; Bora, T.; Claereboudt, M.; Al-Abri, M.; Dutta, J. Visible light photocatalytic degradation of HPAM polymer in oil produced water using supported zinc oxide nanorods. Chem. Eng. J. 2018, 351, 56-64. [CrossRef]

50. Liu, B.; Chen, B.; Zhang, B.; Jing, L.; Zhang, H.; Lee, K. Photocatalytic Degradation of Polycyclic Aromatic Hydrocarbons in Offshore Produced Water: Effects of Water Matrix. J. Environ. Eng. 2016, 142, 04016054. [CrossRef]

51. Sheikholeslami, Z.; Kebria, D.Y.; Qaderi, F. Investigation of photocatalytic degradation of BTEX in produced water using $\gamma$-Fe2O3 nanoparticle. J. Therm. Anal. Calorim. 2018, 135, 1617-1627. [CrossRef] 
52. Ahmed, S.N.; Haider, W. Heterogeneous photocatalysis and its potential applications in water and wastewater treatment: A review. Nanotechnology 2018, 29, 342001. [CrossRef] [PubMed]

53. He, Y.; Gao, Y.; Zhang, X.; Dong, Y. Construction of the elements based on lifted multiwavelet and its applications. Integr. Ferroelectr. 2016, 172, 132-141. [CrossRef]

54. Hasegawa, M.C.; Daniel, J.F.D.S.; Takashima, K.; Batista, G.A.; Da Silva, S.M.C.P. COD removal and toxicity decrease from tannery wastewater by zinc oxide-assisted photocatalysis: A case study. Environ. Technol. 2014, 35, 1589-1595. [CrossRef] [PubMed]

55. Çifçi, D.I.; Meric, S.; Optimization of Suspended photocatalytic treatment of two biologically treated textile effluents using TiO2 and ZnO catalysts. Glob. NEST J. 2015, 17, 653-663. Available online: https://journal.gnest. org/sites/default/files/Submissions/gnest_01715/gnest_01715_published.pdf (accessed on 1 August 2020).

56. Tsoumachidou, S.; Velegraki, T.; Antoniadis, A.; Poulios, I. Greywater as a sustainable water source: A photocatalytic treatment technology under artificial and solar illumination. J. Environ. Manag. 2017, 195, 232-241. [CrossRef]

57. Saverini, M.; Catanzaro, I.; Sciandrello, G.; Avellone, G.; Indelicato, S.; Marci, G.; Palmisano, L. Genotoxicity of citrus wastewater in prokaryotic and eukaryotic cells and efficiency of heterogeneous photocatalysis by TiO2. J. Photochem. Photobiol. B Biol. 2012, 108, 8-15. [CrossRef]

58. Calleja, A.; Baldasano, J.M.; Mulet, A. Toxicity analysis of leachates from hazardous wastes via microtox anddaphnia magna. Environ. Toxicol. Water Qual. 1986, 1,73-83. [CrossRef]

59. Corrêa, A.X.; Tiepo, E.N.; Somensi, C.A.; Sperb, R.M.; Radetski, C.M. Use of ozone-photocatalytic oxidation (O 3/UV/TiO 2) and biological remediation for treatment of produced water from petroleum refineries. J. Environ. Eng. 2010, 136, 40-45. [CrossRef]

60. Chong, M.N.; Jin, B.; Chow, C.; Saint, C.; Saint, C. Recent developments in photocatalytic water treatment technology: A review. Water Res. 2010, 44, 2997-3027. [CrossRef]

61. Sundar, K.P.; Kanmani, S. Progression of Photocatalytic reactors and it's comparison: A Review. Chem. Eng. Res. Des. 2020, 154, 135-150. [CrossRef]

62. Sirtori, C.; Agüera, A.; Gernjak, W.; Malato, S. Effect of water-matrix composition on Trimethoprim solar photodegradation kinetics and pathways. Water Res. 2010, 44, 2735-2744. [CrossRef] [PubMed]

63. Katz, A.; McDonagh, A.; Tijing, L.D.; Shon, H.K. Fouling and inactivation of titanium dioxide-based photocatalytic systems. Crit. Rev. Environ. Sci. Technol. 2015, 45, 1880-1915. [CrossRef]

64. Rincón, A. Effect of $\mathrm{pH}$, inorganic ions, organic matter and $\mathrm{H} 2 \mathrm{O} 2$ on E. coli K12 photocatalytic inactivation by TiO2Implications in solar water disinfection. Appl. Catal. B Environ. 2004, 51, 283-302. [CrossRef]

65. Keen, O.; McKay, G.; Mezyk, S.; Linden, K.G.; Rosario-Ortiz, F.L. Identifying the factors that influence the reactivity of effluent organic matter with hydroxyl radicals. Water Res. 2014, 50, 408-419. [CrossRef]

66. Nogueira, A.A.; Bassin, J.P.; Cerqueira, A.C.; Dezotti, M. Integration of biofiltration and advanced oxidation processes for tertiary treatment of an oil refinery wastewater aiming at water reuse. Environ. Sci. Pollut. Res. 2016, 23, 9730-9741. [CrossRef]

67. Liu, P.; Ren, Y.; Ma, W.; Ma, J.; Du, Y. Degradation of shale gas produced water by magnetic porous MFe2O4 $(\mathrm{M}=\mathrm{Cu}, \mathrm{Ni}, \mathrm{Co}$ and $\mathrm{Zn})$ heterogeneous catalyzed ozone. Chem. Eng. J. 2018, 345, 98-106. [CrossRef]

68. Friehs, E.; AlSalka, Y.; Jonczyk, R.; Lavrentieva, A.; Jochums, A.; Walter, J.-G.; Stahl, F.; Scheper, T.; Bahnemann, D.W. Toxicity, phototoxicity and biocidal activity of nanoparticles employed in photocatalysis. J. Photochem. Photobiol. C Photochem. Rev. 2016, 29, 1-28. [CrossRef]

69. Lee, W.-M.; An, Y.-J. Effects of zinc oxide and titanium dioxide nanoparticles on green algae under visible, UVA, and UVB irradiations: No evidence of enhanced algal toxicity under UV pre-irradiation. Chemosphere 2013, 91, 536-544. [CrossRef]

70. Miller, R.; Bennett, S.; Keller, A.A.; Pease, S.; Lenihan, H.S. TiO2 Nanoparticles Are Phototoxic to Marine Phytoplankton. PLoS ONE 2012, 7, e30321. [CrossRef]

71. Dalai, S.; Pakrashi, S.; Kumar, R.S.S.; Chandrasekaran, N.; Mukherjee, A. A comparative cytotoxicity study of TiO2 nanoparticles under light and dark conditions at low exposure concentrations. Toxicol. Res. 2012, 1, 116. [CrossRef]

72. Adams, L.K.; Lyon, D.Y.; Alvarez, P. Comparative eco-toxicity of nanoscale TiO2, SiO2, and ZnO water suspensions. Water Res. 2006, 40, 3527-3532. [CrossRef] [PubMed]

73. Tong, T.; Binh, C.T.T.; Kelly, J.J.; Gaillard, J.-F.; Gray, K.A. Cytotoxicity of commercial nano-TiO2 to Escherichia coli assessed by high-throughput screening: Effects of environmental factors. Water Res. 2013, 47, 2352-2362. [CrossRef] [PubMed] 
74. Lipovsky, A.; Nitzan, Y.; Gedanken, A.; Lubart, R. Antifungal activity of ZnO nanoparticles-the role of ROS mediated cell injury. Nanotechnology 2011, 22, 105101. [CrossRef] [PubMed]

75. Simon, M.; Barberet, P.; Delville, M.-H.; Moretto, P.; Seznec, H. Titanium dioxide nanoparticles induced intracellular calcium homeostasis modification in primary human keratinocytes. Towards an in vitro explanation of titanium dioxide nanoparticles toxicity. Nanotoxicology 2010, 5, 125-139. [CrossRef]

76. Yin, J.-J.; Liu, J.; Ehrenshaft, M.; Roberts, J.E.; Fu, P.P.; Mason, R.P.; Zhao, B. Phototoxicity of nano titanium dioxides in HaCaT keratinocytes-generation of reactive oxygen species and cell damage. Toxicol. Appl. Pharmacol. 2012, 263, 81-88. [CrossRef] [PubMed]

77. Mansfield, C.; Alloy, M.; Hamilton, J.; Verbeck, G.; Newton, K.; Klaine, S.; Roberts, A.P. Photo-induced toxicity of titanium dioxide nanoparticles to Daphnia magna under natural sunlight. Chemosphere 2015, 120, 206-210. [CrossRef] [PubMed]

78. Kim, J.; Lee, S.; Kim, C.-M.; Seo, J.; Park, Y.; Kwon, D.; Lee, S.-H.; Yoon, T.H.; Choi, K. Non-monotonic concentration-response relationship of $\mathrm{TiO} 2$ nanoparticles in freshwater cladocerans under environmentally relevant UV-A light. Ecotoxicol. Environ. Saf. 2014, 101, 240-247. [CrossRef]

79. Bar-Ilan, O.; Louis, K.M.; Yang, S.P.; Pedersen, J.A.; Hamers, R.J.; Peterson, R.E.; Heideman, W. Titanium dioxide nanoparticles produce phototoxicity in the developing zebrafish. Nanotoxicology 2011, 6, 670-679. [CrossRef]

80. Faria, M.; Navas, J.M.; Soares, A.; Barata, C. Oxidative stress effects of titanium dioxide nanoparticle aggregates in zebrafish embryos. Sci. Total Environ. 2014, 470, 379-389. [CrossRef]

81. Dasari, T.P.; Pathakoti, K.; Hwang, H.-M. Determination of the mechanism of photoinduced toxicity of selected metal oxide nanoparticles $(\mathrm{ZnO}, \mathrm{CuO}, \mathrm{Co} 3 \mathrm{O} 4$ and $\mathrm{TiO} 2)$ to E. coli bacteria. J. Environ. Sci. 2013, 25, 882-888. [CrossRef]

82. Kim, J.; Park, Y.; Yoon, T.H.; Yoon, C.; Choi, K. Phototoxicity of CdSe/ZnSe quantum dots with surface coatings of 3-mercaptopropionic acid or tri-n-octylphosphine oxide/gum arabic in Daphnia magna under environmentally relevant UV-B light. Aquat. Toxicol. 2010, 97, 116-124. [CrossRef] [PubMed]

83. Kahru, A.; Dubourguier, H.-C.; Blinova, I.; Ivask, A.; Kasemets, K. Biotests and Biosensors for Ecotoxicology of Metal Oxide Nanoparticles: A Minireview. Sensors 2008, 8, 5153-5170. [CrossRef] [PubMed]

84. Bour, A.; Mouchet, F.; Silvestre, J.; Gauthier, L.; Pinelli, E. Environmentally relevant approaches to assess nanoparticles ecotoxicity: A review. J. Hazard. Mater. 2015, 283, 764-777. [CrossRef]

85. Bahadar, H.; Maqbool, F.; Niaz, K.; Abdollahi, M. Toxicity of Nanoparticles and an Overview of Current Experimental Models. Iran. Biomed. J. 2015, 20, 1-11. [PubMed]

86. Pinedo, A.; Lopez, M.; Leyva, E.; Zermeño, B.; Serrano, B.; Moctezuma, E. Photocatalytic Decomposition of Metoprolol and Its Intermediate Organic Reaction Products: Kinetics and Degradation Pathway. Int. J. Chem. React. Eng. 2016, 14, 809-820. [CrossRef]

87. Berberidou, C.; Kitsiou, V.; Lambropoulou, D.A.; Michailidou, D.; Kouras, A.; Poulios, I. Decomposition and detoxification of the insecticide thiacloprid by $\mathrm{TiO} 2$-mediated photocatalysis: Kinetics, intermediate products and transformation pathways. J. Chem. Technol. Biotechnol. 2019, 94, 2475-2486. [CrossRef]

88. Trinh, D.T.T.; Le, S.T.T.; Channei, D.; Khanitchaidecha, W.; Nakaruk, A. Investigation of Intermediate Compounds of Phenol in Photocatalysis Process. Int. J. Chem. Eng. Appl. 2016, 7, 273-276. [CrossRef]

89. Kim, D.-H.; Lee, D.; Monllor-Satoca, D.; Kim, K.; Lee, W.; Choi, W. Homogeneous photocatalytic Fe3+/Fe2+ redox cycle for simultaneous $\mathrm{Cr}$ (VI) reduction and organic pollutant oxidation: Roles of hydroxyl radical and degradation intermediates. J. Hazard. Mater. 2019, 372, 121-128. [CrossRef]

90. Santos, I.; Hildenbrand, Z.L.; Schug, K.A. A Review of Analytical Methods for Characterizing the Potential Environmental Impacts of Unconventional Oil and Gas Development. Anal. Chem. 2018, 91, 689-703. [CrossRef]

91. Oetjen, K.; Giddings, C.G.; McLaughlin, M.; Nell, M.; Blotevogel, J.; Helbling, D.E.; Mueller, D.; Higgins, C.P. Emerging analytical methods for the characterization and quantification of organic contaminants in flowback and produced water. Trends Environ. Anal. Chem. 2017, 15, 12-23. [CrossRef]

92. Luek, J.L.; Gonsior, M. Organic compounds in hydraulic fracturing fluids and wastewaters: A review. Water Res. 2017, 123, 536-548. [CrossRef] [PubMed]

93. Akyon, B.; McLaughlin, M.; Hernandez, F.; Blotevogel, J.; Bibby, K. Characterization and biological removal of organic compounds from hydraulic fracturing produced water. Environ. Sci. Process. Impacts 2019, 21, 279-290. [CrossRef] [PubMed] 
94. Sitterley, K.A.; Linden, K.G.; Ferrer, I.; Thurman, E.M. Identification of Proprietary Amino Ethoxylates in Hydraulic Fracturing Wastewater Using Liquid Chromatography/Time-of-Flight Mass Spectrometry with Solid-Phase Extraction. Anal. Chem. 2018, 90, 10927-10934. [CrossRef]

95. Pichtel, J. Oil and Gas Production Wastewater: Soil Contamination and Pollution Prevention. Appl. Environ. Soil Sci. 2016, 2016, 1-24. [CrossRef]

96. Ray, J.P.; Engelhardt, F.R. Produced Water: Technological/Environmental Issues and Solutions; Springer Science \& Business Media: Berlin, Germany, 2012; Volume 46.

97. U.S. Environmental Protection Agency (EPA). Integrated Risk Information System (IRIS) on Baygon; National Center for Environmental Assessment, Office of Research and Development: Washington, DC, USA, 1999.

98. Litter, M.I.; Quici, N. New Advances in Heterogeneous Photocatalysis for Treatment of Toxic Metals and Arsenic. Nanomater. Environ. Prot. 2014, 143-167. [CrossRef]

99. Litter, M.I. Treatment of Chromium, Mercury, Lead, Uranium, and Arsenic in Water by Heterogeneous Photocatalysis. Chem. Eng. Renew. Convers. 2009, 36, 37-67. [CrossRef]

100. Litter, M.I.; Morgada, M.E.; Bundschuh, J. Possible treatments for arsenic removal in Latin American waters for human consumption. Environ. Pollut. 2010, 158, 1105-1118. [CrossRef]

101. Bundschuh, J.; Litter, M.I.; Ciminelli, V.S.; Morgada, M.E.; Cornejo, L.; Hoyos, S.E.G.; Hoinkis, J.; Alarcón-Herrera, M.T.; Armienta-Hernández, M.A.; Bhattacharya, P. Emerging mitigation needs and sustainable options for solving the arsenic problems of rural and isolated urban areas in Latin America-A critical analysis. Water Res. 2010, 44, 5828-5845. [CrossRef]

102. Fostier, A.H.; Pereira, M.D.S.S.; Rath, S.; Guimarães, J.R. Arsenic removal from water employing heterogeneous photocatalysis with TiO2 immobilized in PET bottles. Chemosphere 2008, 72, 319-324. [CrossRef]

103. Abdel-Maksoud, Y.; Imam, E.H.; Ramadan, A.R. TiO2 Solar Photocatalytic Reactor Systems: Selection of Reactor Design for Scale-up and Commercialization-Analytical Review. Catalysts 2016, 6, 138. [CrossRef]

104. Kukovecz, A.; Kordas, K.; Kiss, J.; Konya, Z. Atomic scale characterization and surface chemistry of metal modified titanate nanotubes and nanowires. Surf. Sci. Rep. 2016, 71, 473-546. [CrossRef]

105. Bavykin, D.V.; Friedrich, J.M.; Walsh, F.C. Protonated Titanates and TiO2 Nanostructured Materials: Synthesis, Properties, and Applications. Adv. Mater. 2006, 18, 2807-2824. [CrossRef]

106. Umebayashi, T.; Yamaki, T.; Itoh, H.; Asai, K. Analysis of electronic structures of $3 \mathrm{~d}$ transition metal-doped TiO2 based on band calculations. J. Phys. Chem. Solids 2002, 63, 1909-1920. [CrossRef]

107. Yu, H.; Irie, H.; Hashimoto, K. Conduction Band Energy Level Control of Titanium Dioxide: Toward an Efficient Visible-Light-Sensitive Photocatalyst. J. Am. Chem. Soc. 2010, 132, 6898-6899. [CrossRef]

108. Choi, W.; Termin, A.; Hoffmann, M.R. The Role of Metal Ion Dopants in Quantum-Sized TiO2: Correlation between Photoreactivity and Charge Carrier Recombination Dynamics. J. Phys. Chem. 1994, 98, 13669-13679. [CrossRef]

109. Jiménez, S.; Micó, M.M.; Arnaldos, M.; Ferrero, E.; Malfeito, J.J.; Medina, F.; Contreras, S. Integrated processes for produced water polishing: Enhanced flotation/sedimentation combined with advanced oxidation processes. Chemosphere 2017, 168, 309-317. [CrossRef]

110. Mazzeo, D.E.C.; Levy, C.E.; Angelis, D.D.F.D.; Marin-Morales, M.A. BTEX biodegradation by bacteria from effluents of petroleum refinery. Sci. Total Environ. 2010, 408, 4334-4340. [CrossRef]

111. Oller, I.; Malato, S.; Pérez, J.S. Combination of Advanced Oxidation Processes and biological treatments for wastewater decontamination-A review. Sci. Total Environ. 2011, 409, 4141-4166. [CrossRef]

112. Waghmode, T.R.; Kurade, M.B.; Sapkal, R.T.; Bhosale, C.H.; Jeon, B.-H.; Govindwar, S.P. Sequential photocatalysis and biological treatment for the enhanced degradation of the persistent azo dye methyl red. J. Hazard. Mater. 2019, 371, 115-122. [CrossRef]

113. Parrino, F.; Corsino, S.F.; Bellardita, M.; Loddo, V.; Palmisano, L.; Torregrossa, M.; Viviani, G. Sequential biological and photocatalysis based treatments for shipboard slop purification: A pilot plant investigation. Process. Saf. Environ. Prot. 2019, 125, 288-296. [CrossRef]

114. Hamdi, H.; Namane, A.; Hank, D.; Hellal, A. Coupling of photocatalysis and biological treatment for phenol degradation: Application of factorial design methodology. J. Mater. 2017, 8, 3953-3961.

(C) 2020 by the authors. Licensee MDPI, Basel, Switzerland. This article is an open access article distributed under the terms and conditions of the Creative Commons Attribution (CC BY) license (http://creativecommons.org/licenses/by/4.0/). 